\title{
Analysis of a Hybrid PV/Thermal Solar-Assisted Heat Pump System for Sports Center Water Heating Application
}

\author{
Y. Bai, ${ }^{1}$ T. T. Chow, ${ }^{1}$ C. Ménézo, ${ }^{2,3}$ and P. Dupeyrat ${ }^{4}$ \\ ${ }^{1}$ BEETRU-BST, City University of Hong Kong, Kowloon, Hong Kong \\ ${ }^{2}$ CETHIL UMR 5008, CNRS/INSA/UCB-Lyon 1, 69621 Lyon, France \\ ${ }^{3}$ LOCIE, FRE CNRS 3220, Université de Savoie, Savoie Technolac, 73370 Le Bourget-du-lac, France \\ ${ }^{4}$ Département EnerBaT, EDF ReD, 77818 Moret sur Loing, France \\ Correspondence should be addressed to Y.Bai, yubai3@cityu.edu.hk
}

Received 6 May 2012; Accepted 13 June 2012

Academic Editor: G. N. Tiwari

Copyright ( $) 2012$ Y. Bai et al. This is an open access article distributed under the Creative Commons Attribution License, which permits unrestricted use, distribution, and reproduction in any medium, provided the original work is properly cited.

The application of solar energy provides an alternative way to replace the primary source of energy, especially for large-scale installations. Heat pump technology is also an effective means to reduce the consumption of fossil fuels. This paper presents a practical case study of combined hybrid PV/T solar assisted heat pump (SAHP) system for sports center hot water production. The initial design procedure was first presented. The entire system was then modeled with the TRNSYS 16 computation environment and the energy performance was evaluated based on year round simulation results. The results show that the system COP can reach 4.1 under the subtropical climate of Hong Kong, and as compared to the conventional heating system, a high fractional factor of energy saving at $67 \%$ can be obtained. The energy performances of the same system under different climatic conditions, that include three other cities in France, were analyzed and compared. Economic implications were also considered in this study.

\section{Introduction}

There are various applications of solar energy for mediumgrade heating, including water heating, space heating, distillation, and the like. The utilization of solar energy for hot water production is one most popular application. However, large rooftop or other space in buildings is needed for installing enough solar collector arrays to satisfy the full services requirements in the large-scale and/or multipledemand cases. From this point of view, the combined solarassisted heat-pump system appears a suitable alternative, which not only saves building space but also reduces the reliance on utilities electricity supply. The combined system is then able to work more efficiently.

Unlike the conventional solar thermal collectors, the hybrid photovoltaic/thermal (PV/T) collectors make possible higher energy outputs per unit surface area because the absorbed solar radiation is converted into electricity and usable heat simultaneously. The studies on this topic were initiated in the 1970s and since then many innovative systems have been introduced. Several recent technical reviews [1-3] cover the latest developments of PV/T collector designs and their performances in terms of electrical/thermal outputs as well as application potentials. The increased attention and research outputs in this area indicate that hybrid $\mathrm{PV} / \mathrm{T}$ technologies present many attractive features for wide applications and industrialization opportunities for large scale production. Specifically in the research area of hot water co-generation, a series of experimental and numerical studies have been undertaken on the stand-alone and buildingintegrated photovoltaic/water-heating (PV/W) systems for warm climate application [4-6]. The year round thermal and cell conversion efficiencies were found $37.5 \%$ and $9.4 \%$ respectively for the case of BiPV/W application in Hong Kong. The overall heat transmission through the PVW wall was reduced to $38 \%$ of the normal building façade. Santbergen et al. [7] took a detailed analysis of the energy yield of solar domestic hot water systems with covered sheetand-tube PV/T collectors. A detailed quantitative analysis of all loss mechanisms inherent to the PV/T collectors was performed on top of those related to PV modules and conventional thermal collectors. The annual electrical 
efficiencies of the PV/T systems they investigated were found lower than the plain PV systems (up to $14 \%$ relatively) and the annual thermal efficiencies were also lower than the conventional thermal collector systems (up to $19 \%$ relatively). With the aim to improve the overall system performance, many parametric studies have been done [8-11]. Charalambous et al. [8] carried out an optimization study based on the "low-flow" concepts, of which the advantages include improved system performance, smaller pump, reduced size and thickness of tubing and insulation, less construction work and time for the optimum absorber configuration, and thus also cost saving. The optimized flow rate for the header and riser in serpentine PV/T collectors is determined, respectively, by using the EES code. A similar study was taken by Cristofari et al. [9] on copolymer PV/T collectors.

To improve the global system efficiency in large-scale installations of hybrid PV/T technology, the combined use with other efficient energy systems (such as heat pump systems) can be promising.

A number of research investigations have been conducted in the design, modeling, and testing of solar-assisted heat pump systems. Ozgener and Hepbasli [12, 13] reviewed the reported works on energy and exergy analysis of SAHP systems. Bridgeman and Harrison [14] conducted a preliminary experimental evaluation of indirect SAHP system for domestic hot water applications; tests were conducted with a range of evaporator supply temperatures and the results indicated that the COP can span from 2.8 to 3.3, depending on the evaporator and condenser temperatures. Dikici et al. [15] performed an energy-exergy analysis of solar-assisted heat pump system for space heating in a test room of $60 \mathrm{~m}^{2}$. The system COP was determined as 3.08 while the exergy loss of the solar collector was found to be $1.92 \mathrm{~kW}$. The authors concluded that the COP increased when the exergy loss of evaporator decreased. Through system simulation $\mathrm{Li}$ and Yang [16] studied a parallel SAHP system for supplying hot water to a hypothetical residential building; the author concluded that the solar collector area affects the optimum flow rate significantly. Wang et al. [17] developed a novel indirect-expansion solar-assisted multifunctional heat pump (IX-SAMHP). The proposed system not only works in operation modes included in the two household appliances, but also operates in four new energy-saving operation modes for space cooling, space heating, and water heating. The experimental results indicated that the IX-SAMHP on cloudy days can produce hot water with considerable reduction in electricity consumption than a solar water heater and in cold winter can operate in much higher COP (3.5-4.2) than a domestic heat pump. Sterling and Collins [18] carried out a feasibility analysis of an indirect SAHP system for domestic water heating as compared to: (i) a traditional solar domestic hot water system and (ii) an electric domestic hot water system. It was found that the electrical consumption and operating cost were most favorable with the indirect SAHP system.

From our literature review, we found that the experimental and theoretical analysis of hybrid SAHP system for large-scale water heating application is very limited. In this study, an indirect hybrid PV/T solar-assisted heat pump system has been investigated from the initial design phase to the detailed analysis of the annual performance through numerical simulation. The cost investment on the proposed system was also estimated.

\section{System Description}

A hypothetical sports center was taken as a reference case. A perspective view of the building is shown in Figure 1. The floor area of the sports center is $3200 \mathrm{~m}^{2}$, corresponding to $80 \mathrm{~m} \mathrm{(L)} \mathrm{by} 40 \mathrm{~m} \mathrm{(W).} \mathrm{The} \mathrm{provisions} \mathrm{include} \mathrm{an}$ indoor swimming pool, one general-games sport hall, several general minigames rooms, one gym, and the relevant services spaces like changing rooms, canteen, lobby, and office. The central plant room is located at the ground level. In this case study, the designed energy system was used for hot water production to cater for bathing and hand washing in the changing rooms.

A simplified schematic diagram of the proposed PVTSAHP system is presented in Figure 2. The solar heat source is for water preheating. An indirect solar water heating mode was chosen in this case. The solar preheating system mainly consists of an array of hybrid PV/T collectors, a plate heat exchanger, and solar storage tanks. On the hot side of the heat exchanger, the fluid in the thermal collector circulates according to the temperature differential between the collector outlet $T_{1}$ and the bottom of the storage tank $T_{7}$, which was monitored by an on-off differential controller $R_{1}$. Upper and lower dead bands were set at $10^{\circ} \mathrm{C}$ and $2^{\circ} \mathrm{C}$, respectively. On the cold side of the exchanger, cold water is taken from the bottom of the tank and delivered to the heat exchanger connected to the collector where it gains solar energy and returns to the tank at a higher temperature. The water circulation is controlled by the on-off differential controller $R_{2}$ according to the tem differential between the entrance of the heat exchanger on the hot side $T_{2}$ and the bottom of the tank $T_{7}$. The dead bands values are the same as in $R_{1}$. The feed water stream is divided into two parts. On part enters from the bottom of the solar tank, and another part is mixed with the water exiting from the heat pump system. The proportion is controlled by a temperaturecontrolled liquid flow diverter according to the designed load water temperature. After preheating by the solar collector system and the small back-up electric heater in the tank, water then passes through the heat pump for reheating as the temperature is still not reaching the desired delivery water temperature. The internal heater in the solar tank is activated only during the winter season. The external auxiliary heater is functioned to keep the desired pool water temperature, of which the set point temperature should be higher than the required delivery temperature in order to cover the heat losses in the pipe distribution system.

\section{Design of Solar Water Preheating System}

3.1. Calculation of the Daily Heating Demand of the Sports Center. According to the practical design guides of sports 


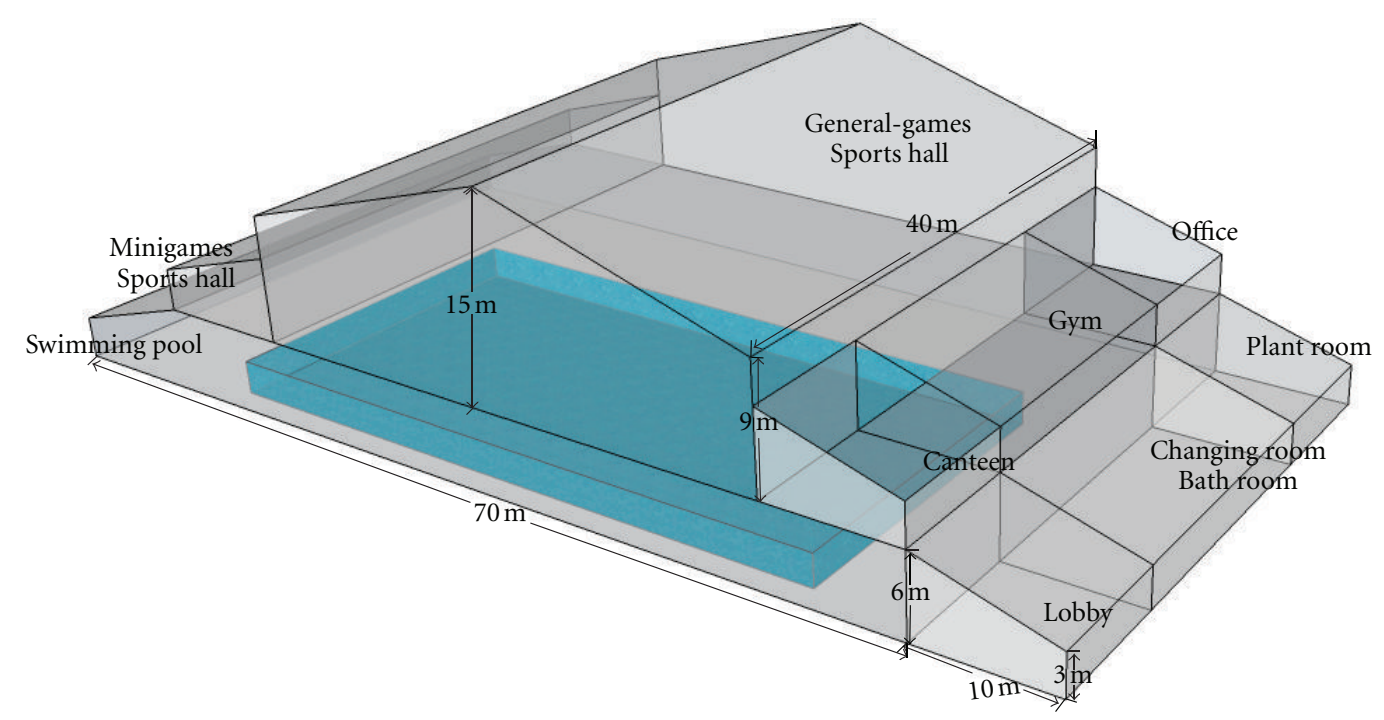

Figure 1: Prospective view of the sports center model.

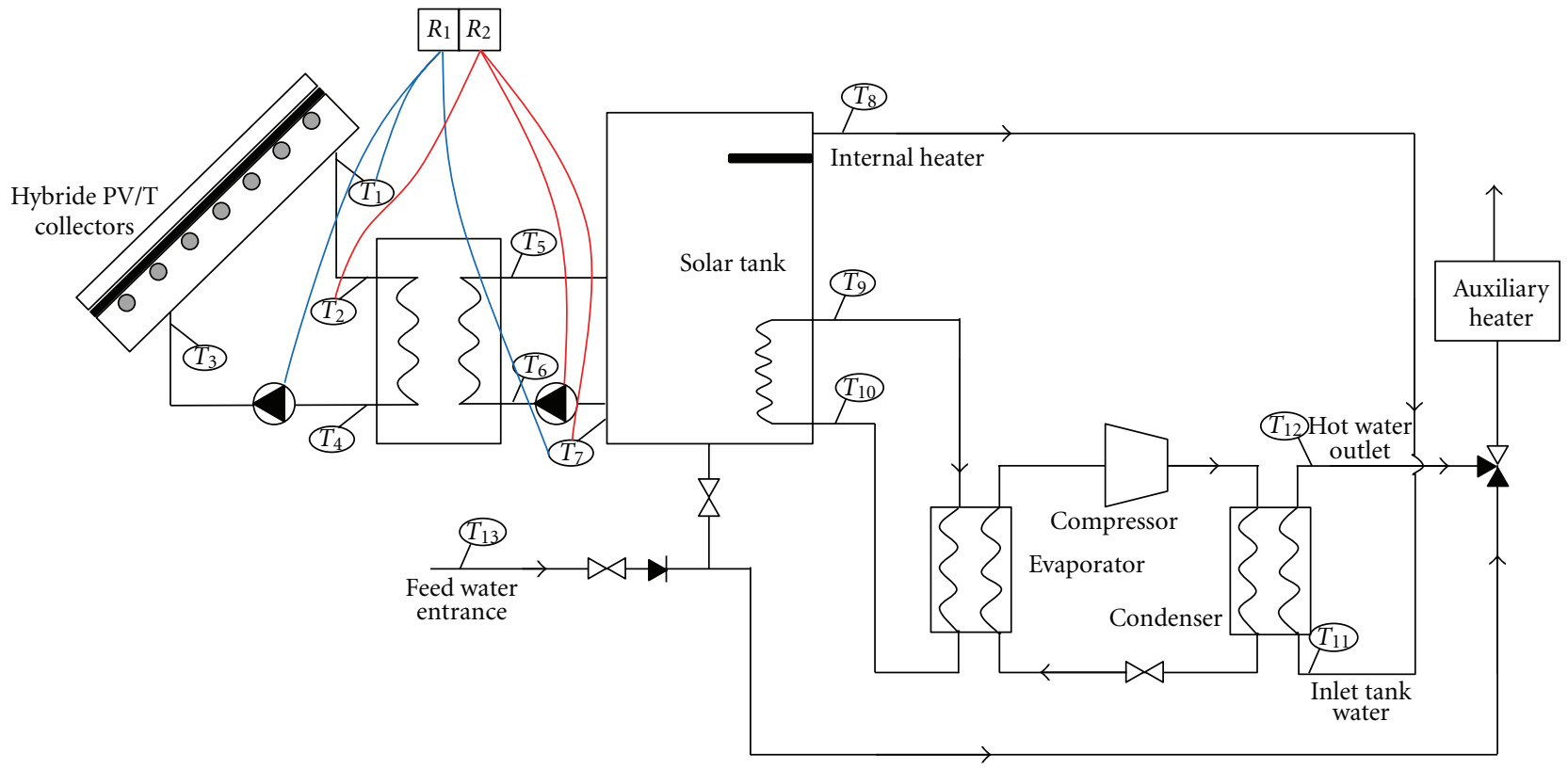

FIgURE 2: Schematic overview of the indirect PV/T solar-assisted heat pump system.

center hot water heating, the water load can be determined according to: (i) the daily average hot water consumption per person or (ii) the hourly water consumption per shower faucet and lavabo.

In our study, the hot water load is calculated by using the daily water load $Q_{h}$, which depends on the number of showers faucets and lavabos in the provision, hence

$$
\dot{m}_{\mathrm{dis}}=\sum q_{h} n_{0} b,
$$

where $q_{h}$ is the hourly water consumption of shower faucets and lavabos, in $\mathrm{kg} / \mathrm{h} ; n_{0}$ is the number of the shower faucets and lavabos, $b$ is the simultaneous using factor of the shower facets and lavabos within one hour, which is usually taken as $100 \%$ for the sports center cases.

The hot water demand is then calculated by:

$$
\dot{m}_{h}=k_{r} \dot{m}_{\text {dis }}
$$

where $k_{r}$ is the hot water mixing factor. This is determined according to the designed hot water temperature at the outlet of the heat pump system and the delivery temperature, as shown (3) that follows:

$$
k_{r}=\frac{T_{\mathrm{dis}}-T_{\mathrm{fw}}}{T_{h}-T_{\mathrm{fw}}},
$$


where $T_{\text {dis }}$ is the delivery water temperature after mixing, in ${ }^{\circ} \mathrm{C}$; $T_{h}$ is the hot water temperature at the outlet of the tank, in ${ }^{\circ} \mathrm{C} ; T_{\mathrm{fw}}$ is the feed water temperature, in ${ }^{\circ} \mathrm{C}$.

The required heating load is then calculated on the basis of:

$$
Q_{h}=\dot{m}_{h} C_{p}\left(T_{h}-T_{\mathrm{fw}}\right)
$$

3.2. Estimation of the Required Solar Collector Area. The required thermal collector area is dependent on several factors including the daily water heating load of the sports center, the collector characteristics, and the climatic conditions. The area of solar collector is determined by the following relation in the direct heating mode:

$$
A_{c d}=\frac{24 Q_{f}}{\left[J_{T} \eta_{c d}\left(1-\eta_{L}\right)\right]},
$$

where $A_{c}$ is the total collector area when the indirect heating mode is used, in $\mathrm{m}^{2} ; J_{T}$ is the average daily solar radiation level, in $\mathrm{kJ} / \mathrm{m}^{2} \cdot \mathrm{d} ; \eta_{L}$ the heat loss coefficient of the hydraulic piping system, normally between 0.2 and 0.3 for the wellinsulated case; $\eta_{c d}$ is the collector efficiency determined by practical test, in general this value varies between 0.25 and 0.5 .

For the indirect heating mode, as in this study, the required collector area is determined on considering the heat exchanger characteristics, as shown in (6):

$$
A_{c}=A_{c d}\left(1+\frac{\delta A_{c d}}{K_{h x} A_{h x}}\right)
$$

where $A_{c d}$ is the total collector area when the direct heating mode is used, in $\mathrm{m}^{2} ; A_{h x}$ is the heat exchanger surface area, in $\mathrm{m}^{2} ; f$ is the general solar fraction according to the different climatic zone; $\delta$ is the collector heat loss coefficient, in $\mathrm{W} /\left(\mathrm{m}^{2} \cdot \mathrm{K}\right) ; K_{h x}$ is the heat transfer coefficient of the heat exchanger, in $\mathrm{W} /\left(\mathrm{m}^{2} \cdot \mathrm{K}\right)$.

In this case study, arbitrarily $\eta_{L}=0.2$ and $\eta_{c d}=0.4$.

3.3. Modeling of the Heat Pump System. In the heat pump unit, the heating capacity of the condenser can be calculated by

$$
Q_{\text {cond }}=m_{\mathrm{rf}}\left(h_{\mathrm{out}}-h_{\mathrm{in}}\right),
$$

where $m_{\mathrm{rf}}$ is mass flow rate of the refrigerant (R410A), $\mathrm{kg} / \mathrm{s}$; $h_{\text {out }}$ and $h_{\text {in }}$ are the specific enthalpy of R410A at the inlet and outlet of the condenser, $\mathrm{kJ} / \mathrm{kg}$.

The heat transfer to water is determined by the following relation:

$$
Q_{\mathrm{dhw}}=m_{\mathrm{dhw}} C_{p}\left(T_{\mathrm{dhw} \_ \text {in }}-T_{\mathrm{dhw} \_ \text {out }}\right),
$$

where $m_{\mathrm{dhw}}$ is mass flow rate of hot water, $\mathrm{kg} / \mathrm{s} ; T_{\mathrm{dhw} \text { in }}$ and $T_{\text {dhw_out }}$ are the inlet and outlet hot water temperatures, ${ }^{\circ} \mathrm{C}$.

The power consumption of the heat pump unit is the total energy consumed by the compressor, water pumps, and the controller, in $\mathrm{kWh}$.

$$
Q_{h p}=\sum_{\tau=0}^{t}\left(P_{\text {comp }}+P_{\text {controller }}+P_{\text {pump }}\right),
$$

where $P_{\text {comp }}, P_{\text {controller, }}$ and $P_{\text {pump }}$ represent the power of the compressor, the controller, and the water pumps, respectively, in $\mathrm{kW}$.

The coefficient of performance of the overall heating system can be defined as

$$
\mathrm{COP}_{\text {sys }}=\frac{Q_{\mathrm{dhw}}}{Q_{\mathrm{hp}}}
$$

\section{System Simulation}

The entire system simulation was carried out based on the initial design parameters under the TRNSYS transient simulation environment [19]. This computer program is popularly used by the international scientific community in the energy and thermal engineering field. It is based on interconnecting elementary modules called TYPE, which are either components of the studied system such as storage tanks or particular functions such as the weather data reader which allows connecting the selected area weather database to the system.

The numerical model of each component used in this study was either available in the existing library or developed as a new component. The hybrid PV/T collector model was developed based on a prototype from the collaborative research of the Fraunhofer Institute for Solar Energy Systems (Fraunhofer ISE) and the National Institute of Applied Science in Lyon, France (INSA Lyon) and with the support of EDF R\&D. In this prototype, the physical configurations of the absorber, that include the water channels and the solar cells, are shown in Figure 3. Four strings of eight pseudosquare sc-Si PV cells were connected in series and laminated with encapsulant and a polymer film onto the surface of a flat Rollbond [20] aluminum heat exchanger with an electric insulating coating. In spite of slightly lower thermal properties than copper, the lower price of aluminum enables a higher plate thickness to be considered $(1 \mathrm{~mm}$ instead of $0.2 \mathrm{~mm}$ ) in order to provide a better stiffness to the solar cells in the absence of glazing $[21,22]$. The absorber was inserted into a collector frame. The collector front cover was a $4 \mathrm{~mm}$ AR glass with a transmission above 0.93 and the distance between the glass cover and the absorber was $20 \mathrm{~mm}$. Thermal insulation material was then applied on the back side of the absorber. The main design data of this prototype is given in Table 1 .

The simulation model is based on a nodal approach originally developed by Fraisse et al. [24, 25] and later modified by Dupeyrat et al. [26] according to the actual physical arrangements. 12 temperature nodes have been considered for the different interfaces from the cover to the backside of the collector including the collector fluid temperature. The nodal temperatures then can be obtained by solving the group of equations derived from the energy balance of each interface. This "TYPE" is different from the other models of solar thermal collectors in TRNSYS because it takes into account several important dynamic properties such as: 


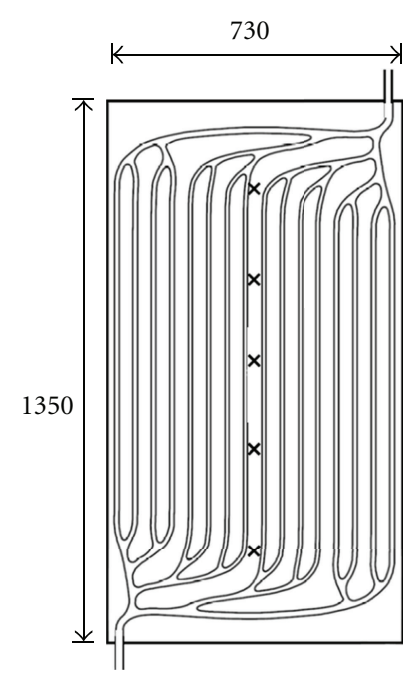

(a)

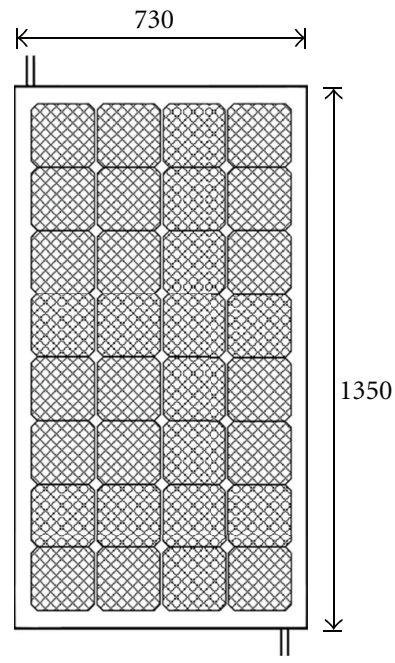

(b)

FIgURE 3: Description of the PV-T absorber plate rear side (a) and front side (b) [23].

TABLE 1: Key parameters of the PVT collector unit.

\begin{tabular}{lc}
\hline Front glazing & \\
Thickness of glass & $0.004 \mathrm{~m}$ \\
Emissivity of glass & 0.9 \\
Thermal capacity & $840 \mathrm{~kJ} /(\mathrm{kg} \cdot \mathrm{K})$ \\
Density & $2500 \mathrm{~kg} / \mathrm{m}^{3}$ \\
Depth of air gap underneath & $0.02 \mathrm{~mm}$ \\
PV cell & \\
Length of the PV cell & $0.156 \mathrm{~m}$ \\
Width of the PV cell & $0.156 \mathrm{~m}$ \\
Thickness & $0.0002 \mathrm{~m}$ \\
Thermal conductivity & $148 \mathrm{~W} /(\mathrm{m} \cdot \mathrm{K})$ \\
Emissivity & 0.91 \\
Absorptivity & 0.93 \\
Reference electrical efficiency of the sc-Si module & $14 \%$ \\
Packing factor & 0.79 \\
Thermal absorber & \\
Length of the module & $1.350 \mathrm{~m}$ \\
Width of the module & $0.73 \mathrm{~m}$ \\
Thermal capacity & $910 \mathrm{~kJ} /(\mathrm{kg} \cdot \mathrm{K})$ \\
Density & $2700 \mathrm{~kg} / \mathrm{m}^{3}$ \\
Absorptivity & 0.94 \\
Number of tubes & 16 \\
Thickness of insulation layer & $0.05 \mathrm{~m}$ \\
Insulation thermal conductivity & $0.04 \mathrm{~W} /(\mathrm{m} \cdot \mathrm{K})$ \\
\hline
\end{tabular}

(i) the long-wave radiation exchange between the cover and the environment (exchanges between the ground and sky are separated),

(ii) the thermophysical characteristics of the collector (instead of the empirical correlation obtained from experiments).
For the evaluation of the convective exchange in the sealed-air channel between the PV cell layer and the cover, the air properties are determined as a function of the air temperature (instead of using constant values). The coefficients of correlation are obtained from the experimental results.

(i) Energy balance of the cover

$$
\begin{aligned}
C_{C} \frac{T_{C F}-T_{C I}}{\Delta t}= & K_{1}\left(T_{A F}-T_{C F}\right)+K_{C 1}\left(T_{\mathrm{amb}}-T_{C F}\right) \\
& +K_{R 1}\left(T_{s}-T_{C F}\right)+B_{c} \mathrm{GA}_{C}
\end{aligned}
$$

with:

$$
\begin{gathered}
C_{C}=\rho_{C} \cdot e_{C} \cdot A_{C} \cdot C p_{C}, \\
K_{1}=A_{C}\left(h_{c i}+h_{r i}\right), \\
K_{C 1}=A_{C}\left(h_{c}+h_{r i}\right), \\
K_{R 1}=A_{C} h_{r s}
\end{gathered}
$$

$T_{C I}$ and $T_{C F}$ are the cover temperatures at the beginning and the end of every time step, $K$; $\rho_{C}$ is the cover density, $\mathrm{kg} / \mathrm{m}^{3}$; $e_{C}$ is the thickness of the cover, $\mathrm{m} ; C p_{C}$ is the specific heat of the cover, $\mathrm{kJ} /(\mathrm{kg} \cdot \mathrm{K}) ; h_{c i}$ is the convective heat transfer coefficient between the absorber and the cover, $\mathrm{W} /\left(\mathrm{m}^{2} \cdot \mathrm{K}\right) ; h_{r i}$ is the radiative heat transfer coefficient between the absorber and the cover, $\mathrm{W} /\left(\mathrm{m}^{2} \cdot \mathrm{K}\right) ; h_{c}$ is the convective heat transfer coefficient between the cover and ambience, $\mathrm{W} /\left(\mathrm{m}^{2} \cdot \mathrm{K}\right) ; h_{r s}$ is the radiative heat transfer coefficient between the cover and the sky, $\mathrm{W} /\left(\mathrm{m}^{2} \cdot \mathrm{K}\right)$.

(ii) Energy balance of the absorber

$$
\begin{aligned}
\mathrm{C}_{A} \frac{T_{A F}-T_{A I}}{\Delta t}= & K_{1}\left(T_{C F}-T_{A F}\right)+K_{2}\left(T_{\mathrm{bs}}-T_{A F}\right) \\
& +K_{3}\left(T_{f}-T_{A F}\right)+\mathrm{BGA}_{C}
\end{aligned}
$$


with:

$$
\begin{aligned}
C_{A}= & \rho_{A} \cdot e_{A} \cdot A_{C} \cdot C p_{A} \\
& +\rho_{T} \cdot C p_{T} \cdot \frac{\pi}{4} \cdot\left[\left(D_{T}+2 \cdot e_{T}\right)^{2}-D_{T}^{2}\right] \cdot L_{T} \cdot N_{T} .
\end{aligned}
$$

The heating capacity of the absorber including the tubes can be written as

$$
\begin{aligned}
& K_{2}=\frac{A_{C}}{e_{\text {ins }} / \lambda_{\text {ins }}+1 / h_{\mathrm{bs}}}, \\
& K_{3}=h_{0} \pi D_{T} L_{T} N_{T},
\end{aligned}
$$

where, $T_{A I}$ and $T_{A F}$ are the absorber temperatures at the beginning and the end of the time step respectively, $K$; $B$ is the optical factor of the absorber; $\rho_{A}$ is the absorber density, $\mathrm{kg} / \mathrm{m}^{3} ; e_{A}$ is the thickness of the absorber, $m ; C p_{A}$ is the specific heat of the absorber, $\mathrm{kJ} /(\mathrm{kg} \cdot \mathrm{K}) ; \rho_{T}$ is the tube density, $\mathrm{kg} / \mathrm{m}^{3} ; e_{T}$ is the thickness of the tube, $m ; C p_{T}$ is the specific heat of the tube, $\mathrm{kJ} /(\mathrm{kg} \cdot \mathrm{K}) ; D_{T}$ is the diameter of the tubes, $m ; L_{T}$ is the length of the tubes, $m ; N_{T}$ is the number of tubes; $\mathrm{e}_{\text {ins }}$ is the thickness of the insulation, $m ; \lambda_{\text {ins }}$ is the thermal conductivity of the insulation, $\mathrm{W} /(\mathrm{m} \cdot \mathrm{K}) ; T_{\mathrm{bs}}$ is the collector backside temperature, ${ }^{\circ} \mathrm{C} ; h_{0}$ is the convective heat transfer coefficient of the fluid, $\mathrm{W} /\left(\mathrm{m}^{2} \cdot \mathrm{K}\right)$.

(iii) Energy balance of the fluid

$$
C_{f} \frac{T_{f F}-T_{f I}}{\Delta t}=K_{4}\left(T_{i f}-T_{f F}\right)+K_{3}\left(T_{A F}-T_{f F}\right),
$$

where,

$$
\begin{gathered}
C_{f}=\rho_{f} \cdot C p_{f} \cdot \frac{\pi D_{T}^{2}}{4} \cdot L_{T} \cdot N_{T}, \\
K_{4}=\frac{\dot{m}_{f} \cdot C p_{f}}{\left(1 /\left(1-e^{-\alpha L_{T}}\right)-1 / \alpha L_{T}\right)}, \\
\alpha=\frac{h_{0} \pi D_{T}}{\left(\dot{m}_{f} \cdot C p_{f} \cdot N_{T}\right)} .
\end{gathered}
$$

$T_{f I}$ and $T_{f F}$ are the fluid temperatures at the beginning and the end of the time step, $K ; \rho_{f}$ is the fluid density, $\mathrm{kg} / \mathrm{m}$; $C p_{f}$ is the specific heat of the cover, $\left.\mathrm{kJ} / \mathrm{kg} \cdot \mathrm{K}\right) ; \dot{m}_{f}$ is the fluid mass flow rate, $\mathrm{kg} / \mathrm{s}$.

The electrical efficiency is determined as follows:

$$
\mathrm{Eff}_{\mathrm{PV}}=\mathrm{Eff}_{\mathrm{PV} \_ \text {_ef }} \cdot\left(1+\beta_{r}\left(T_{\mathrm{PV}}-T_{\mathrm{PV}_{\text {_ref }}}\right)\right) \cdot \gamma \cdot \tau_{1},
$$

where $\gamma$ is the PV cell packing factor, $\tau_{1}$ is the transmittance of the covers, $\mathrm{Eff}_{\mathrm{PV} \text { _ref }}$ is the reference cell efficiency at the reference operating temperature $T_{\mathrm{PV}_{-} \text {ref }}=298.15 \mathrm{~K} ; T_{\mathrm{PV}}$ is the PV cell surface temperature, $\mathrm{K} ; \beta_{r}$ is the temperature coefficient, $\% / \mathrm{K}$.

At every time step, the exchange coefficients are to be calculated by using the initial temperatures of the nodes. The three differential equations, namely, (11), (13), and (16), which are defined according to the energy balance of every nodes, are solved numerically.
TABLE 2: Simulation parameters of sanitary equipment and required temperature.

\begin{tabular}{lc}
\hline Mass flow rate per shower equipment & $300 \mathrm{~L} / \mathrm{h}$ \\
Mass flow rate per lavabo & $30 \mathrm{~L} / \mathrm{h}$ \\
Number of the shower equipment & 150 \\
Number of the lavabo & 80 \\
Bathing water temperature & $35^{\circ} \mathrm{C}$ \\
\hline
\end{tabular}

TABLE 3: Simulation parameters of the solar water preheating system.

\begin{tabular}{ll}
\hline Collectors area & $600 \mathrm{~m}^{2}$ \\
Number of collectors in series & 10 \\
Number of the array group in parallel & 12 \\
Mass flow rate & $40 \mathrm{~L} / \mathrm{h} \cdot \mathrm{m}^{2}$ \\
Auxiliary heater power & $5 \mathrm{~kW}$ \\
Tank model with internal coil exchanger & Horizontal cylinder tank \\
Orientation/tilt angle & South-facing/23 \\
\hline
\end{tabular}

TABle 4: Water source heat pump unit characteristics under the standard condition.

\begin{tabular}{ll}
\hline Type of refrigerant & $\mathrm{R} 410 \mathrm{~A}$ \\
Heat capacity & $14.61 \mathrm{~kW}\left(40^{\circ} \mathrm{C} / 45^{\circ} \mathrm{C}\right.$ hot water, constant flow $)$ \\
C.O.P & 4.9 \\
Cooling capacity & $10.37\left(12^{\circ} \mathrm{C} / 7^{\circ} \mathrm{C}\right.$ chilled water, constant flow $)$ \\
E.E.R & 4.5 \\
\hline
\end{tabular}

The storage tank (Type 60) was modeled as a component of the vertical stratified cylindrical tank including internal heat exchanger. The thermal stratification can be modeled by assuming that the tank consists of $N(N \leqslant 100)$ fully mixed equal volume segments. The degree of stratification is determined by the value of $N$. If $N$ is equal to 1 , the storage tank is modeled as a fully mixed tank and no stratification effects are possible.

Listed in Tables 2, 3 and 4 are the system parameters and input data considered in the simulation process.

\section{Results and Discussion}

Both the system energy and exergy performance were determined. The year round simulation results were obtained using the typical meteorological year (TMY) hourly weather data of Hong Kong. The simulation time step was 12 minutes.

5.1. Energy Evaluation Criteria. The rate of useful thermal energy produced from the PV/T collector can be evaluated as:

$$
Q_{u}=\dot{m}_{f} C_{p}\left(T_{o c}-T_{i c}\right) .
$$

The electrical energy generated in $\mathrm{kWh}$ is given by:

$$
E_{\text {elect }}=\mathrm{Eff}_{\mathrm{PV}} \cdot A c \cdot G
$$


Annual thermal equivalent of electrical energy produced can be evaluated by using:

$$
Q_{\text {elecannual }}=\frac{E_{\text {elecannual }}}{0.38} .
$$

An efficiency of 0.38 was arbitrarily used for the conversion of thermal energy into electrical energy for thermal power plants.

The overall annual thermal output can be evaluated by:

$$
Q_{t}=Q_{\text {elecannual }}+Q_{\text {uannual }} \cdot
$$

Collector thermal efficiency, which is the ratio of the useful energy gain $Q_{u}$ to the absorbed solar energy by the collectors, can be evaluated using (23), in that

$$
\mathrm{Eff}_{\text {thermal }}=\frac{Q_{u}}{\left(A_{C} G\right)} .
$$

The fraction of energy saving is another evaluation criterion to estimate the system performance as compared to the conventional system by using the primary source energy. It can be determined by:

$$
Q_{\text {sav }}=Q_{\text {convention }}-Q_{\text {aux }},
$$

where, $Q_{\text {aux }}$ is the sum of the auxiliary consumption including the energy consumption of the auxiliary heater, the components (compressor, pumps, and, etc.) in the heat pump system:

$$
F_{\text {sav }}=\frac{Q_{\text {sav }}}{Q_{\text {convention }}} .
$$

5.2. Energy Evaluation Criteria. The exergy output is critical to define the real performance of PV/T system [25-27]. This can be calculated from the expression given by Fraisse et al. [28], as follows:

$$
Q_{\text {exth }}=\sum_{k=1}^{12} \sum_{j=1}^{N} \sum_{i=1}^{n} \dot{Q_{u}}\left(1-\frac{T_{a}}{T_{\text {sun }}}\right),
$$

where $T_{a}$ is the ambient temperature in Kevin, and $T_{\text {sun }}$ is temperature of the sun $(5777 \mathrm{~K})$.

As the electrical output of a PV/W collector is a form of exergy, the total annual exergy output of the collector can be obtained by

$$
Q_{\text {exann }}=E_{\text {elect }}+Q_{\text {exth }} .
$$

The exergy from the solar radiation can be given by:

$$
Q_{\text {exsolar }}=G A\left(1-\frac{T_{a}}{T_{\text {sun }}}\right) .
$$

The exergy efficiency of the collector then can be calculated by

$$
\mathrm{Eff}_{\text {excol }}=\frac{Q_{\text {exann }}}{Q_{\text {exsolar }}} .
$$

The exergy efficiency of the overall system is then given as:

$$
\mathrm{Eff}_{\text {exsys }}=\frac{\dot{m}_{m} C_{p}\left(T_{\mathrm{dis}}-T_{\mathrm{fw}}\right)-T_{a} \dot{m}_{m} \ln \left(T_{\mathrm{dis}} / T_{\mathrm{fw}}\right)+E_{\text {elect }}}{Q_{\text {exsolar }}+Q_{\text {aux }}} .
$$

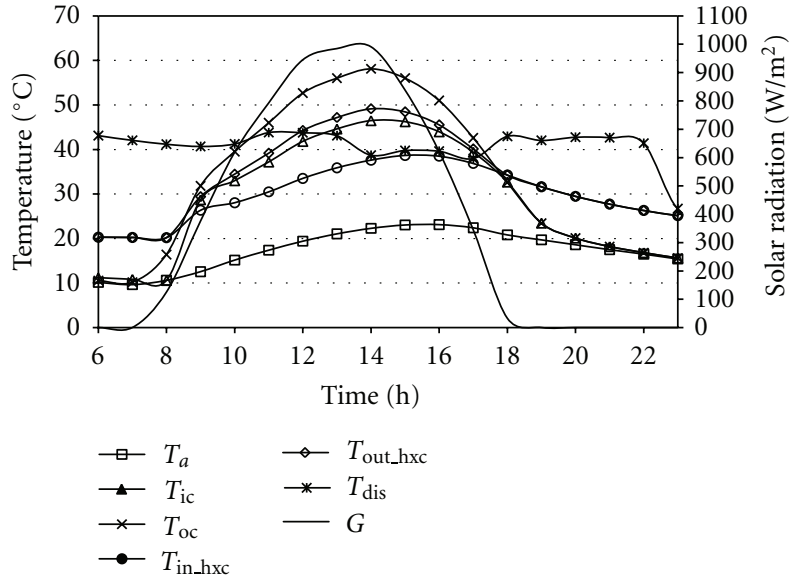

FIgURE 4: Daily variation of temperatures and the incident solar radiation, mi February.

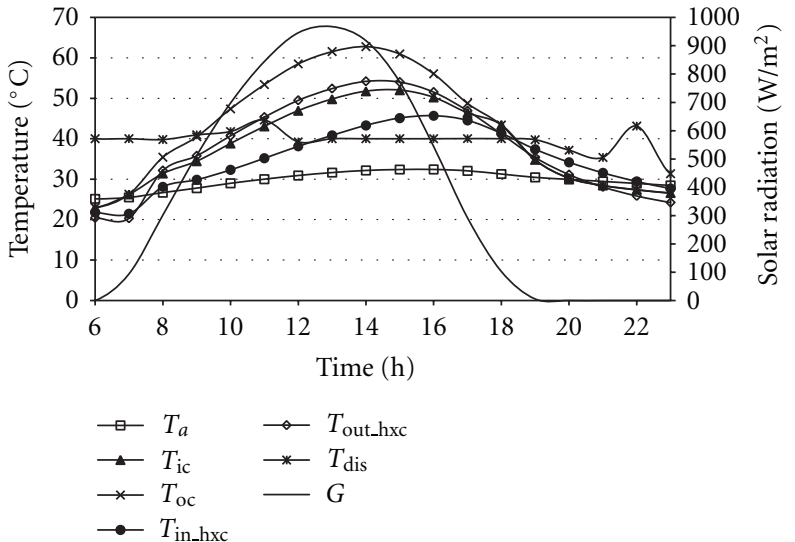

FIGURE 5: Daily variation of temperatures and the incident solar radiation, mi August.

5.3. Daily and Monthly System Energy and Exergy Performance in Hong Kong. Figures 4-5 show the variations of the collector inlet and outlet water temperatures (hot side of the heat exchanger), cold side inlet, and outlet temperatures of the heat exchanger connected to tank, delivery water temperature, and the outdoor air temperature of two typical sunny days, one in winter (mid February) and the other in summer (mid August) of Hong Kong. The mass flow rates in the solar loop and in the heat exchanger-tank loop are $2400 \mathrm{l} / \mathrm{h}$ and $2000 \mathrm{l} / \mathrm{h}$, respectively. The fluid circulation on both sides is regulated by the corresponding temperature differential controller. During the system operating period, the temperature difference between the inlet and outlet of the solar collectors can be close to $10^{\circ} \mathrm{C}$ when there is water flow in the solar loop. As expected, the temperature of load water $T_{\text {dis }}$ could be maintained around $40^{\circ} \mathrm{C}$, which is slight higher than the expected pool water temperature on considering the heat losses in pipe distribution. The collector temperature is found higher in summer than in winter for the same solar radiation level. 
TABLE 5: Annual energy and exergy assessment of the designed system under different climates.

\begin{tabular}{|c|c|c|c|c|c|c|}
\hline City & $\begin{array}{c}\text { Solar radiation } \\
\quad(\mathrm{kWh})\end{array}$ & $\begin{array}{l}\text { Collector useful } \\
\text { thermal energy } \\
(\mathrm{kWh})\end{array}$ & $\begin{array}{l}\text { Collector } \\
\text { electrical output } \\
(\mathrm{kWh})\end{array}$ & $\begin{array}{l}\text { Overall thermal } \\
\text { output (kWh) }\end{array}$ & $\begin{array}{l}\text { Exergy output } \\
\quad(\mathrm{kWh})\end{array}$ & $\begin{array}{c}\text { Auxiliary energy } \\
\text { consumption } \\
(\mathrm{kWh})\end{array}$ \\
\hline Hong Kong & $8.74 E+05$ & $4.31 E+05$ & $9.00 E+04$ & $1.21 E+06$ & $1.29 E+05$ & $4.19 E+05$ \\
\hline Paris & $6.74 E+05$ & $2.93 E+05$ & $7.24 E+04$ & $1.63 E+06$ & $1.29 E+05$ & $6.26 E+05$ \\
\hline Lyon & $7.82 E+05$ & $3.46 E+05$ & $8.28 E+04$ & $1.76 E+06$ & $1.89 E+05$ & $5.29 E+05$ \\
\hline Nice & $9.78 E+05$ & $4.71 E+05$ & $1.02 E+05$ & $1.79 E+06$ & $1.83 E+05$ & $4.67 E+05$ \\
\hline
\end{tabular}

TABLE 6: Annual efficiencies of the designed system.

\begin{tabular}{|c|c|c|c|c|c|c|}
\hline City & $\begin{array}{l}\text { Col. electrical } \\
\text { efficiency }(\%)\end{array}$ & $\begin{array}{l}\text { Col. thermal } \\
\text { efficiency }(\%)\end{array}$ & $\begin{array}{c}\text { Col. overall } \\
\text { efficiency }(\%)\end{array}$ & $\begin{array}{c}\text { Exergy } \\
\text { efficiency }(\%)\end{array}$ & $\begin{array}{l}\text { C.O.P of HP } \\
\text { system }(\%)\end{array}$ & $\begin{array}{c}\text { Fraction of energy } \\
\text { saving }(\%)\end{array}$ \\
\hline Hong Kong & 10.29 & 49.24 & 76.32 & 10.06 & 4.11 & 66.55 \\
\hline Paris & 10.75 & 43.45 & 71.73 & 9.85 & 4.34 & 67.98 \\
\hline Lyon & 10.59 & 44.29 & 72.16 & 9.13 & 4.52 & 71.05 \\
\hline Nice & 10.42 & 48.11 & 75.54 & 11.93 & 4.34 & 75.63 \\
\hline
\end{tabular}

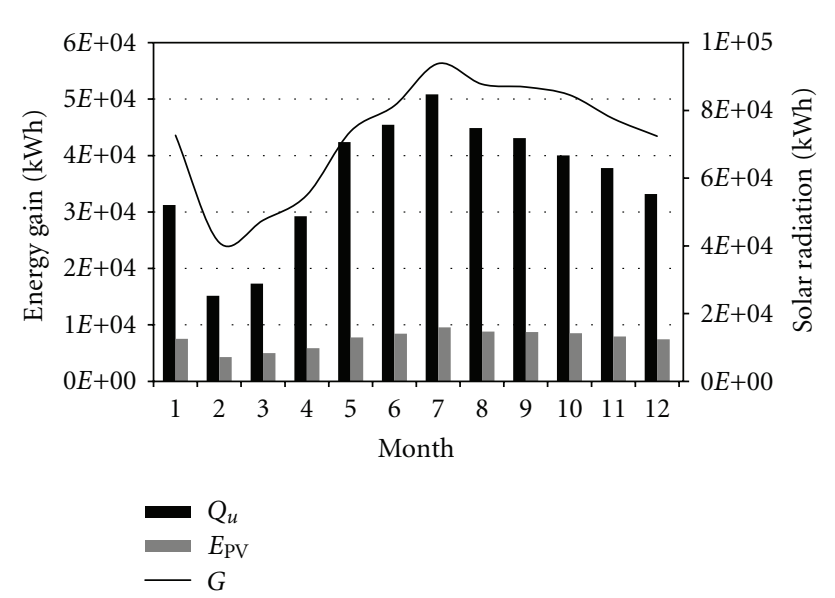

Figure 6: Monthly thermal and electrical energy gain of arrays of solar collectors and the incident solar radiation.

The monthly energy gain of the hybrid collectors is shown in Figure 6. $Q_{u}$ represents the useful thermal output of the collectors. $E_{\mathrm{pv}}$ represents the electricity generation from the collectors. It can be observed that the variation of the heat gain of the solar collectors agrees well with the incident solar radiation. The heat gain is low during the first quarter of the year as the solar radiation level is also relatively low in this period. The highest useful heat gain of $5.08 E+04 \mathrm{kWh}$ and the electricity generation of $9.57 E+03 \mathrm{kWh}$ as well are obtained in July. As shown in Figure 7, the collector thermal efficiency varies between 0.37 and 0.57 over the year. But the PV electrical efficiency is relatively constant (fluctuating between $10.1 \%$ and $10.7 \%$ ). The year round thermal and electrical efficiencies are $49.3 \%$ and $10.3 \%$, respectively. The combined energy efficiency is then $76.3 \%$, with 0.38 as the conversion factor.

Figure 8 shows the solar energy delivered to the tank $Q_{\text {hxc }}$ and the total energy auxiliary energy consumption of the system (auxiliary heater, heat pump components). It can
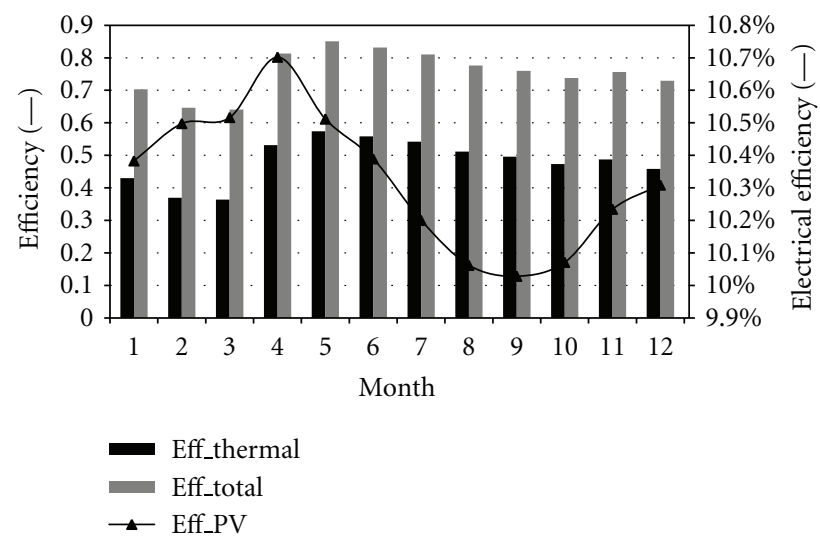

Figure 7: Monthly collector efficiencies.

be observed that the transferred solar energy via the heat exchanger is slightly lower than the useful thermal energy collected in the collector. This is because of the heat losses induced by the heat exchanger. The overall auxiliary energy consumption is more important for the winter season. This is when the small internal auxiliary heater is activated to keep the desired water temperature before the reheating by the heat pump system. Compared to the conventional electrical heating system, the monthly fraction of energy saving was around $65 \%$ over the winter period. This fraction became higher in the warm season and was around $90 \%$.

The monthly thermal performance of the heat pump series and the system COP are given in Figure 9. $Q_{\mathrm{hw}}$ represents the heat transfer to hot water; $Q_{h p}$ is the sum of the energy consumption of the compressor and the controller in the heat pump system. The energy consumption of the heat pump system is more important for the winter season when the water temperature exiting the storage tank is relatively low. More reheat energy is needed to push up to the desired delivery temperature. The system COP in the warm season is relatively low. This is so especially during the last three 
TABLE 7: Investment of the designed system.

\begin{tabular}{|c|c|c|c|c|}
\hline \multicolumn{5}{|l|}{ System configuration } \\
\hline Component & Hong Kong & Paris & Lyon & Nice \\
\hline Collector area $\left(\mathrm{m}^{2}\right)$ & 600 & 600 & 600 & 600 \\
\hline Heat pump heating capacity $(\mathrm{kW})$ & 175 & 270 & 240 & 220 \\
\hline Power of auxiliary heater unit (kW) & 15 & 15 & 50 & 50 \\
\hline Storage tank $\left(\mathrm{m}^{3}\right)$ & 60 & 60 & 60 & 60 \\
\hline \multicolumn{5}{|l|}{ Cost $(\mathrm{HK} \$)$} \\
\hline Solar collectors & $5.10 E+06$ & $6.00 E+06$ & $6.00 E+06$ & $6.00 E+06$ \\
\hline Water tank & $4.02 E+05$ & $2.40 E+06$ & $2.40 E+06$ & $2.40 E+06$ \\
\hline Auxiliary heater & $5.94 E+03$ & $1.05 E+04$ & $1.05 E+04$ & $1.05 E+04$ \\
\hline Heat pump systems & $2.78 E+05$ & $3.20 E+06$ & $2.56 E+06$ & $2.40 E+06$ \\
\hline Accessories & $5.38 E+05$ & $9.20 E+05$ & $8.56 E+05$ & $8.40 E+05$ \\
\hline Transportation & $2.18 E+04$ & $2.24 E+05$ & $1.98 E+05$ & $1.92 E+05$ \\
\hline Cost of Balance of system plus site installation and testing & $1.50 E+04$ & $4.60 E+05$ & $4.28 E+05$ & $4.20 E+05$ \\
\hline Total investment & $6.36 E+06$ & $1.32 E+07$ & $1.25 E+07$ & $1.23 E+07$ \\
\hline Tax reduction and governmental subvention (percentage of total investment) & NA & $13 \%$ & $13 \%$ & $13 \%$ \\
\hline Energy saving $(\mathrm{kWh})$ & $6.72 E+05$ & $1.19 E+06$ & $1.12 E+06$ & $1.16 E+06$ \\
\hline Payback period & 10.52 & 8.82 & 8.83 & 8.40 \\
\hline
\end{tabular}

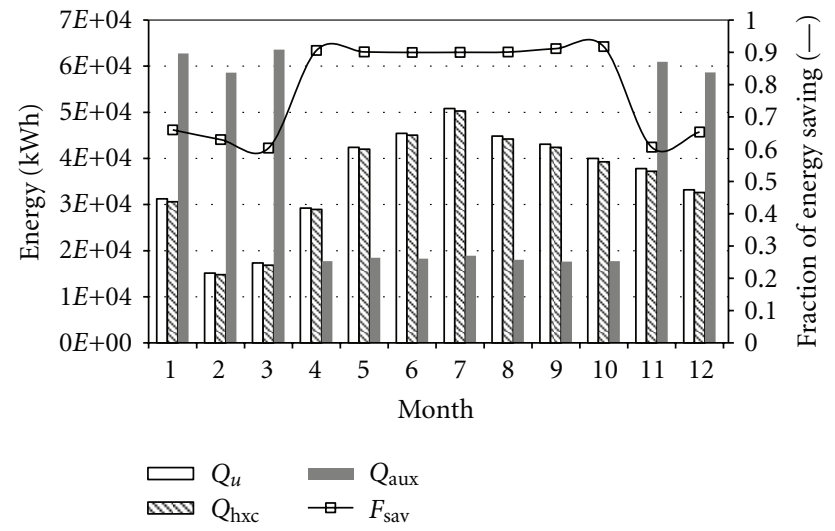

FIGURE 8: Monthly system auxiliary energy consumption and the energy saving.

summer months when the temperature of heat source turns high, and this affects the heat pump performance.

5.4. Comparison of Annual Energy and Exergy Performance under Different Climates. The annual energy and exergy performance of the designed system were evaluated under different climates, that is, in Hong Kong under subtropical climate and in three other cities of France. There are three climate zones in France, namely, Oceanic, Continental, and Mediterranean. The three cities Paris, Lyon and Nice, each could represent the typical climatic condition of each zone, were indicated on the map in Figure 10. The selected four cities can represent also most of the similar region climate of the world. The numerical computation of the annual performance was performed based on the hourly TMY weather data of individual cities. All cities were assumed to have the same load profile as in Hong Kong and thereby creating a common basis for comparison. The feed water temperature was determined according to the fresh water temperature and the return load water temperature as shown in Figure 11.

Table 5 lists the estimation of annual energy and exergy performance in the four cities. Regarding the total incident solar radiation, Nice has the highest level of solar radiation which yields also the highest outputs (useful thermal energy at $4.71 E+05 \mathrm{kWh}$ and electricity at $1.02 E+05 \mathrm{kWh})$. Paris has the least energy gains as the solar radiation level and ambient temperature in this zone are relatively low. Consequently, more auxiliary energy was consumed in Paris. In terms of the system thermal output that affected by the freshwater temperature, Hong Kong has the lowest thermal output, at $1.21 E+06 \mathrm{kWh}$. Concerning the exergy output, Hong Kong and Paris are positioned at the same low level, whereas Lyon has the best exergy performance of $1.89 E+$ $05 \mathrm{kWh}$.

The annual system efficiencies are given in Table 6. The electrical efficiency for these four cities vary slightly between $10.29 \%$ and $10.75 \%$. The collector thermal efficiency and the overall efficiency are relatively low for Paris and Lyon and are around 5\% lower than Hong Kong - the city with the highest collector overall efficiency. Concerning the performance of the heat pump series, the system COP remains almost the same for all the cities, and the fraction of energy saving is all around $78 \%$. Overall speaking, the system performs less desirable in exergy efficiency, at around 10\% for all climatic conditions.

\section{Economic Analysis}

The investment on a combined solar-assisted heat pump system includes the material and labour costs of the solar 


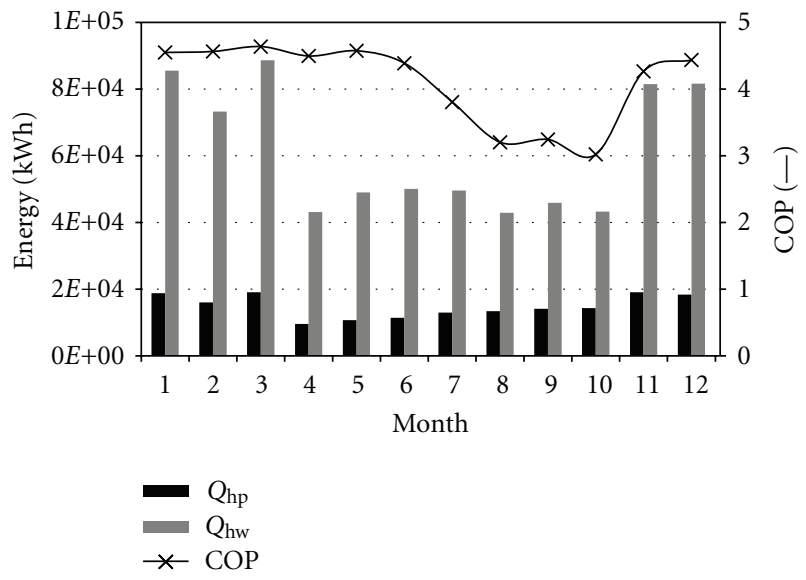

FIGURE 9: Monthly water source heat pump energy consumption and the system COP.

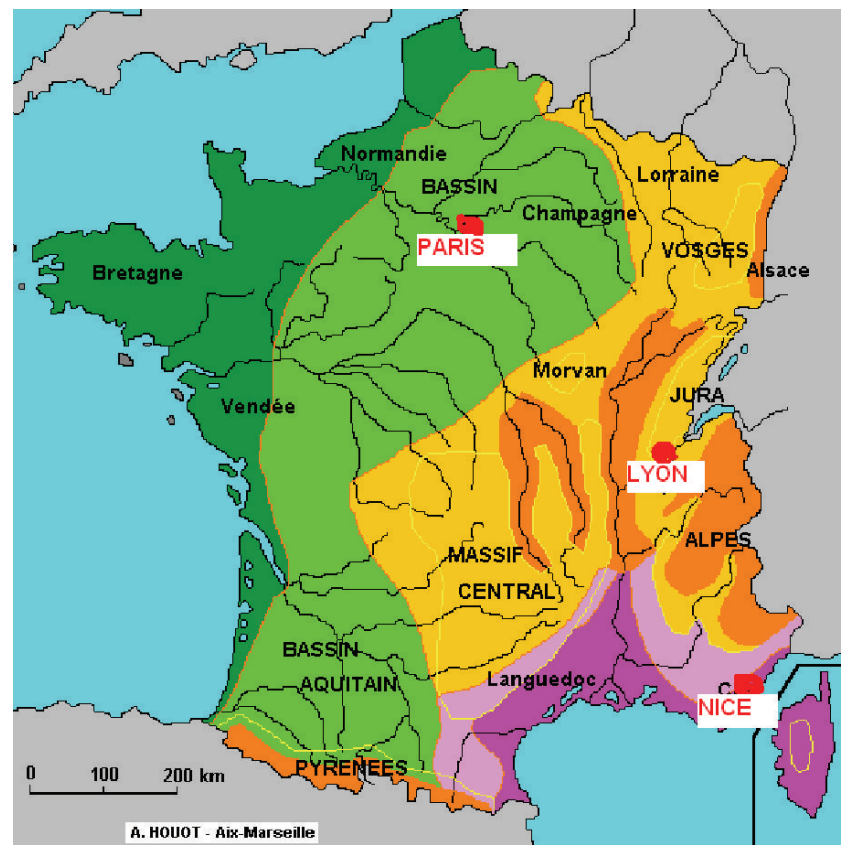
Oceanic
Degrade
PARIS: $48^{\circ} 51^{\prime} 24.12^{\prime \prime} \mathrm{N}, 2^{\circ} 21^{\prime} 2.88^{\prime \prime} \mathrm{E}$
Degrade
Mediterranean
LYON: $45^{\circ} 45^{\prime} 34.92^{\prime \prime} \mathrm{N}, 4^{\circ} 50^{\prime} 31.92^{\prime \prime} \mathrm{E}$
Continental
Degrade
NICE: $43^{\circ} 12^{\prime} 12.24^{\prime \prime} \mathrm{N}, 7^{\circ} 15^{\prime} 58.68^{\prime \prime} \mathrm{E}$

Figure 10: Climatic zones in France.

collectors, thermal storage tank, heat pump series, accessories (such as heat exchanger, pumps, controller, valves and, etc.) and the relevant system test and transportation. By making reference to the expenses of other similar SAHP systems in Hong Kong and in France, the costs of the entire system were evaluated and shown in Table 7 . The most important investment item lies in the solar collectors. In France, according to the low carbon promotion policy, every installation of photovoltaic system could benefit by $11 \%$ tax credit [29] based on the total system investment. In addition, there exist some kinds of local subvention depending on the region and relevant department. In this case study, we took on average $2 \%$ of the total investment as the sum of the subvention. The average cost per $\mathrm{kWh}$ of electricity in Hong Kong is $1 \mathrm{HK} \$$ and this is $0.1074 €$ (equivalent $1.1 \mathrm{HK \$}$ ) [30] in France. The cost payback period was then estimated for each city. The results are listed in Table 7. Hong Kong has the longest payback period of 10.52 years even though the cost of material is less expensive compared to the other French cities. So far in Hong Kong, there is no subvention formulated 


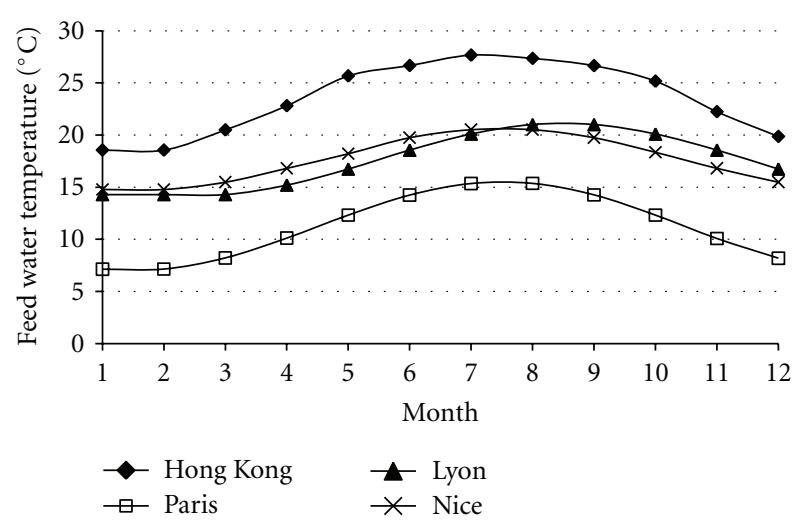

Figure 11: Feed water temperature of different cities.

for the solar thermal or electrical installations. The payback periods for the French cities are all around 9 years. In Nice, the city which possesses the richest annual solar radiation, this could be shortened to 8.4 years. However, the French government lowers the tax reduction for photovoltaic system year by year (25\% for 2010, 22\% for 2011 and 11\% for 2012). The payback period will be probably longer in future, if the technical advancements are not to be considered.

\section{Conclusions}

This study was intended to investigate the potential application of the hybrid PV/T solar-assisted heat pump system for indoor sports centre water heating under the subtropical climatic condition of Hong Kong, as well as the multiple climates in France. An initial design procedure was first presented, and the energy performance was evaluated through the use of the TRNSYS transient simulation tool. The numerical results showed that the designed system can well satisfy the system energy demands. The hot water supply temperature can be reheated to $40^{\circ} \mathrm{C}$ during the operating period. The mean heating COP of the SAHP system is found to be 4.3. The overall efficiency of PV/T collectors can reach $76 \%$ in Hong Kong. The global fractional energy saving factor can achieve a maximum of $75 \%$ in Nice. The payback period of 10.52 years for Hong Kong is comparatively long. The stake of the further research led on this topic should be on the improvement of system exergy efficiency by optimizing the system configuration and parametric studies. The system life cycle assessment should also be in place to assess the environmental impacts.

\section{Nomenclature}

$A_{c}$ : Area of hybrid PV/T collector in indirect heating mode $\left(\mathrm{m}^{2}\right)$

$A_{c d}$ : Area of hybrid PV/T collector in direct heating mode $\left(\mathrm{m}^{2}\right)$

$B: \quad B$ is the optical factor of the absorber $(-)$

$C_{\mathrm{p}}$ : Specific heat of water $(\mathrm{kJ} / \mathrm{kg} \cdot \mathrm{K})$

$e: \quad$ Thickness $(\mathrm{m})$
$E_{\text {elect }}$ Electrical energy generated from the collector $(\mathrm{kWh})$

Eff $_{\text {thermal }}$ : Thermal efficiency of collector $(-)$

Eff $\mathrm{PV}$ : $\quad$ Electrical efficiency of collector $(-)$

$F_{h x}: \quad$ Heat exchanger surface area $\left(\mathrm{m}^{2}\right)$

$G$ : $\quad$ Total incident solar radiation $(\mathrm{kWh})$

$K_{h x}$ : Heat transfer coefficient of the heat exchanger $\left(\mathrm{W} / \mathrm{m}^{2} \cdot \mathrm{K}\right)$

$J_{T}$ : Average daily solar radiation level $\left(\mathrm{kJ} / \mathrm{m}^{2} \cdot\right.$ day $)$

$h_{c}$ : Convective heat transfer coefficient be-

tween the cover and ambience $\left(\mathrm{W} / \mathrm{m}^{2} \cdot \mathrm{K}\right)$

$h_{0}$ : Convective heat transfer coefficient of the fluid, $\left(\mathrm{W} / \mathrm{m}^{2} \cdot \mathrm{K}\right)$

$h_{r i}$ : $\quad$ Radiative heat transfer coefficient between the absorber and the cover $\left(\mathrm{W} / \mathrm{m}^{2} \cdot \mathrm{K}\right)$

$h_{r s}$ : Radiative heat transfer coefficient between the cover and the sky $\left(\mathrm{W} / \mathrm{m}^{2} \cdot \mathrm{K}\right)$

$k_{r}$ : $\quad$ Hot water mixing factor

$\dot{m}_{f}$ : Collector fluid mass-flow rate $(\mathrm{kg} / \mathrm{s})$

$\dot{m}_{h}$ : Mass-flow rate of hot water from the tank (kg/h)

$\dot{m}_{\text {dis }}: \quad$ Mass-flow rate of load water $(\mathrm{kg} / \mathrm{h})$

$i$ : $\quad$ Segment in the tank $(-)$

$Q_{\text {aux }}$ : $\quad$ Total auxiliary energy consumption (kWh)

$Q_{\text {elecannual: Annual thermal equivalent of electrical }}$ energy (kWh)

$Q_{h}: \quad$ Required heat load (kJ/h)

$Q_{\text {uannual }}$ Annual useful thermal energy of collector (kWh)

$Q_{u}$ : $\quad$ Instant useful thermal energy of the solar collector $(\mathrm{kJ} / \mathrm{h})$

$T_{a}: \quad$ Outdoor air temperature $\left({ }^{\circ} \mathrm{C}\right)$

$T_{C I}$ : Collector cover temperature at the beginning of every time step (K)

$T_{C F}$ : Collector cover temperature at the end of every time step $(\mathrm{K})$

$T_{\text {dis }}: \quad$ Load water temperature $\left({ }^{\circ} \mathrm{C}\right)$

$T_{f I}$ : Collector fluid temperature at the end of

$T_{f F}$ : Collector fluid temperature at the end of

every time step $(\mathrm{K})$

$T_{\mathrm{fw}}$ : $\quad$ Feed water temperature $\left({ }^{\circ} \mathrm{C}\right)$

$T_{h}$ : $\quad$ Hot water temperature $\left({ }^{\circ} \mathrm{C}\right)$

$T_{\mathrm{PV}}$ : $\quad$ PV cell surface temperature $\left({ }^{\circ} \mathrm{C}\right)$

$T_{\mathrm{PV} \_ \text {ref: }} \quad$ PV reference operating temperature

$T_{\text {sun }}: \quad$ Sun temperature $(\mathrm{K})$

$U A_{\text {flue }, i}$ : Heat transfer capacity of the fluid in the $i$ segment $(\mathrm{kJ} / \mathrm{h} \cdot \mathrm{K})$

$\Delta x: \quad$ Distance between the segments (m)

$\Delta t: \quad$ Time step for the system simulation (min).

Greek Symbols

$\beta$ : Collector slope $\left(^{\circ}\right)$

$\beta_{r}$ : PV temperature coefficient $(\% / \mathrm{K})$

$\gamma$ : PV cell covering factor $(-)$

$\delta$ : Collector heat loss coefficient $\left(\mathrm{W} / \mathrm{m}^{2} \cdot \mathrm{K}\right)$ 
$\lambda$ : $\quad$ Fluid thermal conductivity $(\mathrm{W} / \mathrm{m} \cdot \mathrm{K})$

$\tau_{1}$ : Transmittance of the cover

$\rho: \quad$ Density $\left(\mathrm{kg} / \mathrm{m}^{3}\right)$

$\eta_{c d}$ : Collector efficiency determined by the practical testing $(-)$

$\eta_{L}$ : Heat loss coefficient of the hydraulic piping system $(-)$.

\section{Acknowledgment}

The research work described in this paper was fully supported by the grants from the Research Grants Council of the Hong Kong Special Administrative Region, China [Project nos. City U 112009 and 112508].

\section{References}

[1] M. A. Hasan and K. Sumathy, "Photovoltaic thermal module concepts and their performance analysis: a review," Renewable and Sustainable Energy Reviews, vol. 14, no. 7, pp. 1845-1859, 2010.

[2] T. T. Chow, "A review on photovoltaic/thermal hybrid solar technology," Applied Energy, vol. 87, no. 2, pp. 365-379, 2010.

[3] T. T. Chow, W. He, and J. Ji, "An experimental study of facade-integrated photovoltaic/water-heating system," Applied Thermal Engineering, vol. 27, no. 1, pp. 37-45, 2007.

[4] T. T. Chow, W. He, and J. Ji, "An experimental study of façade-integrated photovoltaic/water-heating system," Applied Thermal Engineering, vol. 27, no. 1, pp. 37-45, 2007.

[5] T. T. Chow, W. He, A. L. S. Chan, K. F. Fong, Z. Lin, and J. Ji, "Computer modeling and experimental validation of a building-integrated photovoltaic and water heating system," Applied Thermal Engineering, vol. 28, no. 11-12, pp. 13561364, 2008.

[6] T. T. Chow, A. L. S. Chan, K. F. Fong, Z. Lin, W. $\mathrm{He}$, and J. Ji, "Annual performance of building-integrated photovoltaic/water-heating system for warm climate application," Applied Energy, vol. 86, no. 5, pp. 689-696, 2009.

[7] R. Santbergen, C. C. M. Rindt, H. A. Zondag, and R. J. C. van Zolingen, "Detailed analysis of the energy yield of systems with covered sheet-and-tube PVT collectors," Solar Energy, vol. 84, no. 5, pp. 867-878, 2010.

[8] P. G. Charalambous, S. A. Kalogirou, G. G. Maidment, and K. Yiakoumetti, "Optimization of the photovoltaic thermal (PV/T) collector absorber," Solar Energy, vol. 85, no. 5, pp. 871-880, 2011.

[9] C. Cristofari, G. Notton, and J. L. Canaletti, "Thermal behavior of a copolymer PV/Th solar system in low flow rate conditions," Solar Energy, vol. 83, no. 8, pp. 1123-1138, 2009.

[10] A. Tiwari and M. S. Sodha, "Parametric study of various configurations of hybrid PV/thermal air collector: experimental validation of theoretical model," Solar Energy Materials and Solar Cells, vol. 91, no. 1, pp. 17-28, 2007.

[11] O. Zogou and H. Stapountzis, "Flow and heat transfer inside a PV/T collector for building application," Applied energy, vol. 91, no. 1, pp. 103-115, 2012.

[12] O. Ozgener and A. Hepbasli, "A review on the energy and exergy analysis of solar assisted heat pump systems," Renewable and Sustainable Energy Reviews, vol. 11, no. 3, pp. 482-496, 2007.
[13] A. Hepbasli and Y. Kalinci, "A review of heat pump water heating systems," Renewable and Sustainable Energy Reviews, vol. 13, no. 6-7, pp. 1211-1229, 2009.

[14] A. Bridgeeman and S. Harrison, "Preliminary experimental evaluation of indirect solar assisted heat pump systems," in Proceedings of the 3rd Canadian Solar Building Conference, Fredericton, NB, Canada, August 2008.

[15] A. Dikici and A. Akbulut, "Performance characteristics and energy-exergy analysis of solar-assisted heat pump system," Building and Environment, vol. 43, no. 11, pp. 1961-1972, 2008.

[16] H. Li and H. Yang, "Study on performance of solar assisted air source heat pump systems for hot water production in Hong Kong," Applied Energy, vol. 87, no. 9, pp. 2818-2825, 2010.

[17] Q. Wang, Y. Q. Liu, G. F. Liang, J. R. Li, S. F. Sun, and G. M. Chen, "Development and experimental validation of a novel indirect-expansion solar-assisted multifunctional heat pump," Energy and Buildings, vol. 43, no. 2-3, pp. 300-304, 2011.

[18] S. J. Sterling and M. R. Collins, "Feasibility analysis of an indirect heat pump assisted solar domestic hot water system," Applied Energy, vol. 93, pp. 11-17, 2011.

[19] TRNSYS, A Transient Simulation Program, Solar Energy Laboratory, University of Wisconsin, Maidison, Wis, USA, 2003.

[20] Bionicol 2010, Bionicol-Development of a bionic solar collector with aluminum Rollbond absorber-Project status after second year, http://www.bionicol.eu/, 2011.

[21] P. Dupeyrat, C. Ménézo, M. Rommel, and H. M. Henning, "Efficient single glazed flat plate photovoltaic-thermal hybrid collector for domestic hot water system," Solar Energy, vol. 85, no. 7, pp. 1457-1468, 2011.

[22] P. Dupeyrat, C. Ménézo, H. Wirth, and M. Rommel, "Improvement of PV module optical properties for PVthermal hybrid collector application," Solar Energy Materials and Solar Cells, vol. 95, no. 8, pp. 2028-2036, 2011.

[23] P. Dupeyrat, Experimental development and simulation investigation of a photovoltaic-thermal hybrid solar collector [Ph.D. thesis], National Institute of Applied Science, Lyon, France, 2011.

[24] C. Plantier, Etude numérique et expérimentale d'un prototype de chauffe-eau solaire équipé d'un stockage à changement de phase [Ph.D. thesis], University of Savoie, Savoy, France, 2005.

[25] G. Fraisse, C. Ménézo, and K. Johannes, "Energy performance of water hybrid PV/T collectors applied to combisystems of Direct Solar Floor type," Solar Energy, vol. 81, no. 11, pp. 1426-1438, 2007.

[26] P. Dupeyrat, Y. Bai, C. Menezo et al., "Performances énergétiques de capteurs solaires hybrides PV-T pour la production d'eau chaude sanitaire," in Proceedings of the Annual conference of Societe France de Thermique (SFT), Perpignan, France, 2011.

[27] V. Raman, G. N. Tiwari, and H. D. Pandey, "Life cycle cost analysis of a hybrid photovoltaic-thermal water and air collector: a comparison study based on energy and exergy," International Journal of Low Carbon Technologies, vol. 3, no. 3, pp. 173-190, 2008.

[28] G. Fraisse, Y. Bai, N. Le Pierrès, and T. Letz, "Comparative study of various optimization criteria for SDHWS and a suggestion for a new global evaluation," Solar Energy, vol. 83, no. 2, pp. 232-245, 2009.

[29] A. S. Joshi, I. Dincer, and B. V. Reddy, "Analysis of energy and exergy efficiencies for hybrid PV/T systems," International Journal of Low-Carbon Technologies, vol. 6, no. 1, Article ID ctq045, pp. 64-69, 2011. 
[30] M. Bosonac, B. Sorensen, I. Katic, H. Sorensen, B. Nielsen, and J. Badran, "Photovoltaic/thermal solar collector and their potential in Denmark," Final Report. EEP project 1713/000014, 2003. 


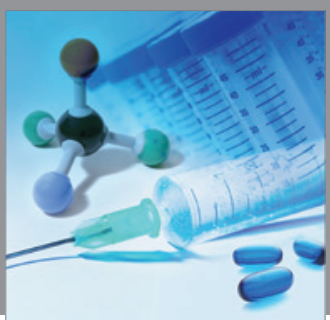

International Journal of

Medicinal Chemistry

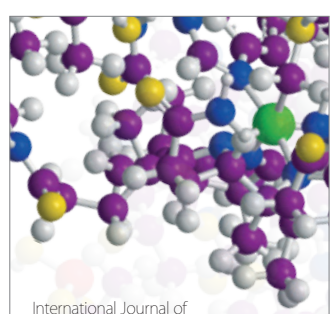

Carbohydrate Chemistry

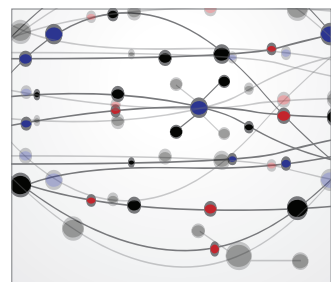

The Scientific World Journal
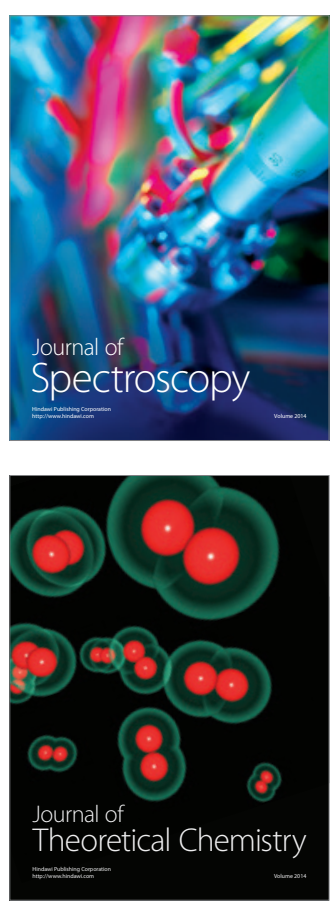
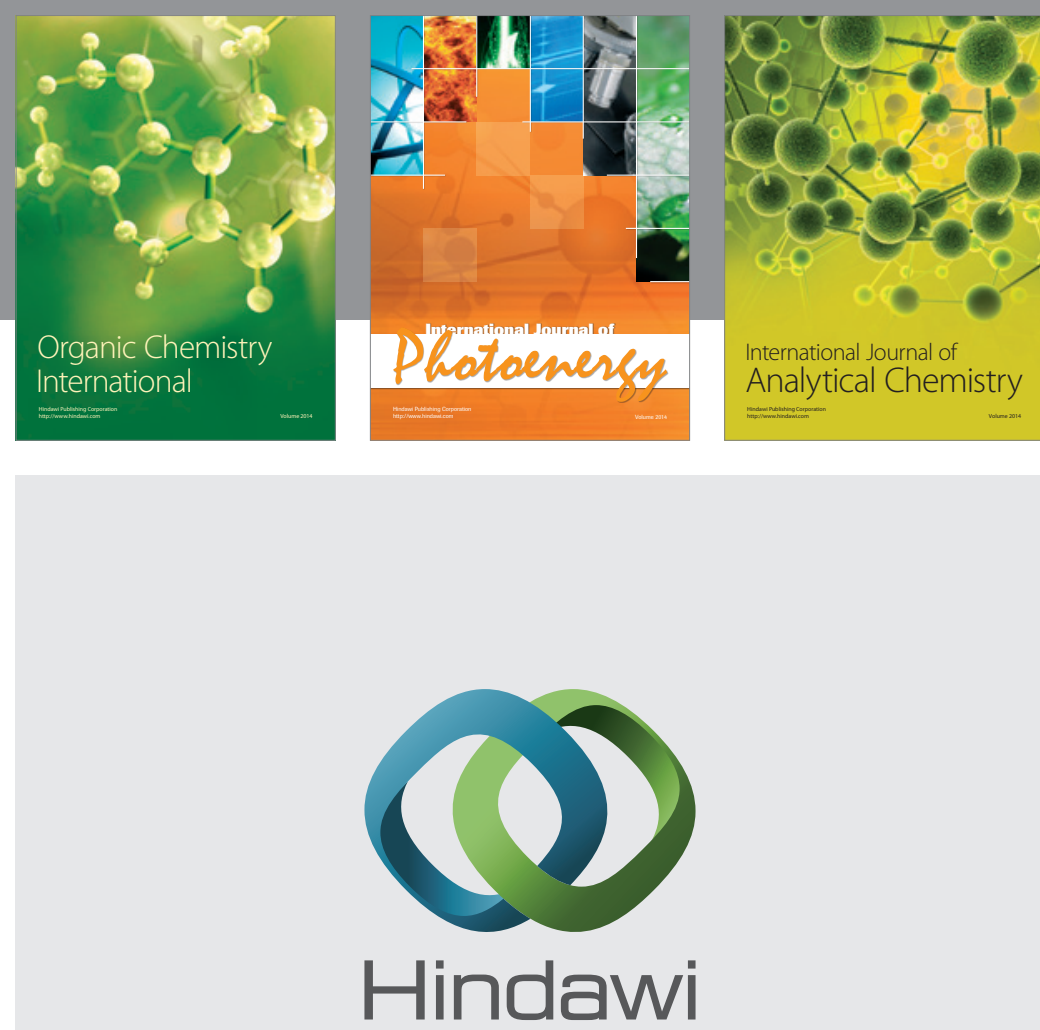

Submit your manuscripts at

http://www.hindawi.com
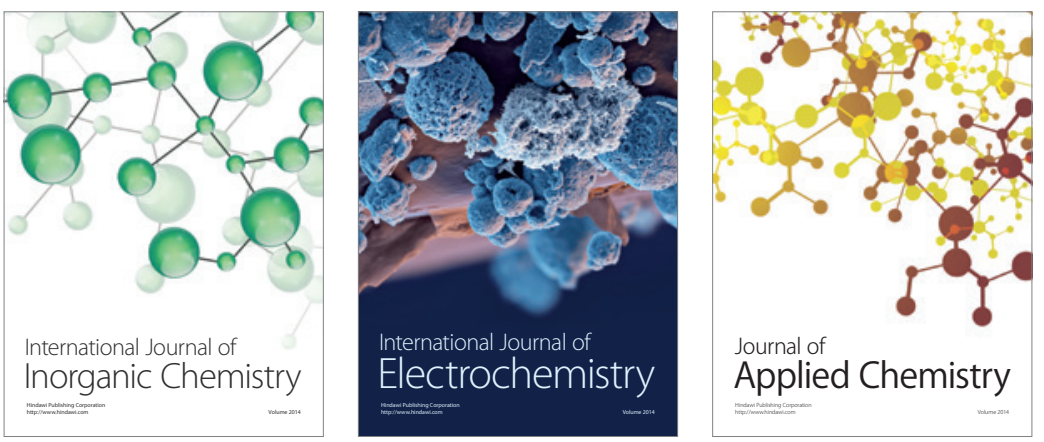

Journal of

Applied Chemistry
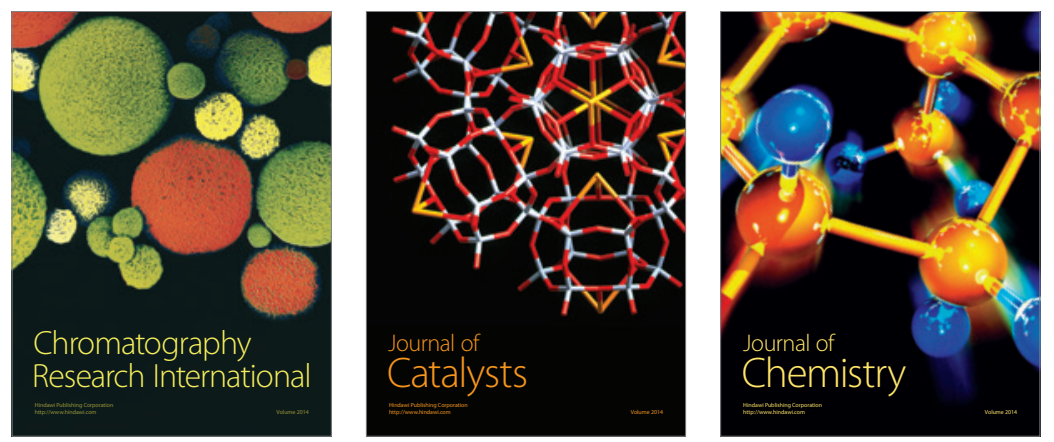
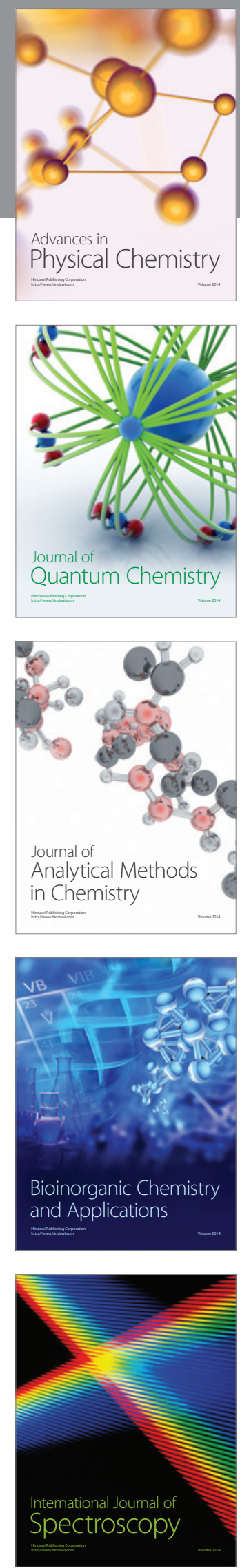